\title{
Keperawatan Galuh
}

https://jurnal.unigal.ac.id/index.php/JKG/article/view/4654

\section{FAKTOR-FAKTOR YANG BERHUBUNGAN DENGAN KEJADIAN GASTRITIS PADA REMAJA DI BANDUNG}

\author{
Maidartati ${ }^{1}$, Tita Puspita Ningrum ${ }^{2}$, Priska Fauzia ${ }^{3}$ \\ 1, 2, 3 Program Studi Ilmu Keperawatan Universitas Adhirajasa Reswara Sanjaya, Indonesia \\ (Sejarah artikel: Diserahkan November 2020, Diterima Desember 2020, Diterbitkan Januari 2021)
}

\begin{abstract}
ABSTRAK
Gastritis adalah peradangan yang mengenai mukosa lambung, dan mengakibatkan pembengkakan mukosa lambung di dalam saluran pencernaan. Keluhan yang dirasakan itu nyeri, dampaknya membuat lambung mengalami kerusakan jika sering kosong karena lambung meremas hingga dinding lambung luka. Tujuan penelitian untuk mengetahui faktor yg berhubungan dengan kejadian gastritis pada remaja di Bandung. Jenis metode penelitian ini menggunakan korelasi, pendekatan cross-sectional, populasi penelitian semua siswa/i di Bandung. Sampel penelitian ini adalah siswa/i SMK Bandung dengan jumlah 150 responden. Pengambilan sampel menggunakan teknik Accidental sampling. Analisa data menggunakan univariat prosentase dan analisa bivariat menggunakan uji Spearman-Rank. Hasil penelitian didapatkan kejadian gastritis sebagian besar atau sebanyak 59 responden (59\%) mengalami gastritis. Hasil statistik pada usia dengan kejadian gastritis diperoleh nilai $p$-value 0.002 dengan nilai $a<0.05$. tidak terdapat hubungan antara faktor jenis kelamin dengan kejadian gastritis. terdapat hubungan antara faktor pola makan dengan kejadian gastritis. tidak terdapat hubungan antara faktor konsumsi alkohol dengan kejadian gastritis. terdapat hubungan antara faktor konsumsi kopi dengan kejadian gastritis. terdapat hubungan antara faktor merokok dengan kejadian gastritis. terdapat hubungan antara faktor kecemasan dengan kejadian gastritis. Saran untuk remaja dan masyarakat agar melakukan pencegahan kejadian gastritis dengan membuka wawasan seluas-luasnya, dan sebagai bahan pertimbangan agar mengetahui faktor yang berhubungan dengan kejadian gastritis pada remaja, dan terhindar dari gastritis yang tidak baik untuk kesehatan.
\end{abstract}

Kata Kunci: Faktor-faktor gastritis, Gastritis, Remaja

ABSTRACT
Gastritis is inflammation that affects the gastric mucosa, and results in swelling of the gastric mucosa in the digestive tract. The complaint that is felt is pain, the impact of which causes damage to the stomach if it is often empty because the stomach squeezes until the stomach wall is abrasions. The aim of this research was to see the factors related to the incidence of gastritis in adolescents in Bandung. This type of research method using computers, cross-sectional approach, the study population of all students in Bandung, which is 100 students. The sample of this study were students of SMK PELITA 2 Bandung with a total of 150 respondents. Sampling using Accidental sampling technique. Data analysis using percentage univariate and bivariate analysis using Spearman-Rank test. The results showed that the incidence of gastritis was mostly or 59 respondents $(59 \%)$ experienced gastritis. Statistical results on age with the incidence of gastritis obtained $\mathrm{p}$ value 0.002 with a value of $a<0.05$. there is no relationship between sex factors and the incidence of gastritis. there is a relationship between dietary factors and the incidence of gastritis. there is no relationship between alcohol consumption and the incidence of gastritis. There is a relationship between coffee consumption and the incidence of gastritis. there is a relationship between smoking and the incidence of gastritis. there is a relationship between the incidence of the incidence of gastritis. Advice for adolescents and the public to prevent the incidence of gastritis by opening the broadest insight possible, and for consideration in order to see the factors associated with the incidence of gastritis in adolescents, and avoid gastritis that is not good for health.

Keywords: Adolescents, Gastritis, Gastritis factors 


\section{PENDAHULUAN}

Pembangunan kesehatan di Indonesia saat ini dihadapkan tidak hanya pada penyakit menular, akan tetapi juga masalah penyakit tidak menular (PTM) dan telah terjadi peningkatan yang disebabkan oleh gaya hidup seseorang. Salah satu masalah kesehatan yang dihadapi sekarang ini adalah penyakit saluran pencernaan seperti gastritis yang banyak dialami usia remaja dan dewasa (Saydam, 2011). Gastritis adalah peradangan mukosa lambung yang dapat bersifat akut, kronik, difus atau lokal yang disebabkan oleh infeksi bacterial Helicobacter pylori ataupun beberapa bahan yang sering dimakan dapat menyebabkan rusaknya sawar mukosa pelindung lambung (Wijaya \& Putri, 2013) Sebagian besar masyarakat masih menganggap gastritis sebagai penyakit yang ringan dan memiliki gejala yang sering dirasakan seperti nyeri pada bagian epigastrium oleh banyak orang, namun hanya menganggap hal tersebut sebagai hal yang biasa bahkan tidak melakukan pemeriksaan lebih lanjut. Gastritis yang dibiarkan akan bertambah parah dan menyebabkan asam lambung meningkat kemudian membuat luka atau ulkus yang sering dikenal sebagai tukak lambung (Muhith \& Siyoto, 2016).

World Health Organization (WHO) memperkirakan angka kematian akibat gastritis di dunia pada tahun 2005 sebesar 40.376 kasus, meningkat menjadi 43.817 kasus pada tahun 2010, dan terus meningkat menjadi 47.269 kasus pada tahun 2015. Persentase angka kejadian gastritis di Indonesia menurut WHO adalah 40\%. Angka kejadian gastritis pada beberapa daerah di Indonesia cukup tinggi dengan prevalensi 274.396 kasus dari 238.452.952 jiwa penduduk. Indonesia mendapat urutan ketiga setelah negara India dan Thailand, yaitu berjumlah 123 ribu penderita penyakit gastritis (Malda, 2018). Penelitian yang dilakukan Departemen Kesehatan RI angka kejadian gastritis di beberapa kota di Indonesia ada yang tinggi mencapai 91,6\% yaitu di kota Medan, lalu di beberapa kota lainya seperti Surabaya 31,2\%, Denpasar $40 \%$, Jakarta $50 \%$, Bandung 32,5\%, Plembang 35,35\%, Aceh 31,7\%, dan Pontianak $31,2 \%$ (Prasetyo, 2016). Penyakit gastritis di Provinsi Jawa Barat mencapai 31,2\% dan di daerah Kota Bandung sendiri penderita penyakit gastritis mencapai 15,37\% (Kemenkes, 2015).

Beberapa faktor risiko yang sering menyebabkan gastritis adalah pola makan yang tidak teratur, memiliki kebiasaan merokok, minum kopi, mengkonsumsi alkohol, usia, dan stress (Ardiansyah, 2012), sedangkan menurut (Huzaifah, 2017) risiko gastritis lebih sering dipicu oleh pola makan yang kurang sesuai, faktor psikis dan kecemasan. Faktor usia. Usia merupakan salah satu

faktor resiko terjadinya gastritis, penyakit ini menyerang semua usia tetapi lebih sering menyerang usia produktif karena gaya hidup yang kurang memperhatikan kesehatan. Gastritis lebih banyak dialami oleh remaja usia 15 sampai 25 tahun yang termasuk ke dalam kelompok usia remaja awal dan remaja akhir. Berdasarkan hasil penelitian Diatsa (2016) menunjukkan bahwa terdapat hubungan antara usia dengan kejadian gastritis, diperoleh nilai $p$-value $(0.000)<0.05$. Mengatakan bahwa yang paling banyak menderita penyakit gastritis adalah responden yang berusia 16 tahun yaitu sebanyak 19 jumlah responden. Usia 16 tahun termasuk ke dalam kategori masa remaja awal. yang berada dalam rentang usia produktif, mereka memiliki kesibukan serta gaya hidup yang kurang diperhatikan sehingga mudah terjadi gastritis.

Berdasarkan berbagai penelitian yang telah dipaparkan di atas, peneliti sangat tertarik melakukan penelitian yang bertujuan mengidentifikasi faktor-faktor yang berhubungan dengan kejadian gastritis pada remaja di Bandung.

\section{METODE PENELITIAN}

Jenis penelitian ini bersifat kuantitatif dengan menggunakan jenis penelitian korelasional dengan desain penelitian adalah menggunakan desain studi potong lintang (Cross sectional). Tehnik pengambilan sampel penelitian menggunakan Accidental sampling dengan jumlah sampel 100 responden. Alat pengumpulan data menggunakan kuisioner. Analisa data univariat menggunakan rumus prosentase dan analisa bivariat menggunakan Rank Spearman.

\section{HASIL PENELITIAN DAN PEMBAHASAN Gambaran Faktor-faktor yang berhubungan dengan Gastritis}

Tabel 1 faktor-faktor yang berhubungan dengan kejadian gastristis

\begin{tabular}{lcc}
\hline karakteristik responden & F & (\%) \\
\hline A. USIA & & \\
1. Remaja Awal (12- & 65 & $65 \%$ \\
16) & & \\
2. Remaja Akhir (17- & 35 & $35 \%$ \\
25) & & \\
B. JENIS KELAMIN & 67 & $33 \%$ \\
$\quad$ 1. Perempuan & 33 & 33 \\
2. Laki-laki & & \\
C. POLA MAKAN & 39 & $39 \%$ \\
$\quad$ 1. Buruk & 47 & $47 \%$ \\
$\quad$ 2. Kurang Baik & 14 & $14 \%$ \\
3. Baik KONSUMSI & & \\
D. KOHOL & & \\
ALKOHing & 0 & $0 \%$ \\
$\quad$ 2. kadang-kadang & 1 & $1 \%$ \\
$\quad$ 3. tidak pernah & 99 & $99 \%$ \\
E. KONSUMSI KOPI & &
\end{tabular}


Eli Kurniasih, Anih Kurnia \& Laila Fitri Istiqomah / Pengaruh Terapi Spiritual (Islam) Terhadap Penurunan Tingkat Kecemasan pada Pasien Hemodialisa

\begin{tabular}{lcc} 
1. sering & 7 & $7 \%$ \\
2. kadang-kadang & 43 & $43 \%$ \\
3. tidak pernah & 50 & $50 \%$ \\
F. MEROKOK & & \\
1. merokok & 7 & $7 \%$ \\
2. tidak merokok & 93 & $93 \%$ \\
G. KECEMASAN & & \\
1. rendah & 34 & $34 \%$ \\
2. sedang & 39 & $39 \%$ \\
3. tinggi & 27 & $27 \%$ \\
\hline
\end{tabular}

Sebagian besar responden yaitu 42 orang (42\%) termasuk usia remaja awal yaitu berusia 16 tahun, berdasarkan jenis kelamin menunjukan bahwa sebagian besar berjenis kelamin perempuan yaitu 67 responden (67\%). Pola makan bawwa sampir separuhnya pola makan kurang baik yaitu 47 responden (47\%). Konsumsi alkohol bahwa hampir seluruhnya tidak pernah mengkonsumsi alkohol yaitu 99 responden (99\%). Konsumsi kopi bahwa separuhnya tidak pernah konsumsi kopi yaitu 50 responden (50\%). Merokok bahwa hampir seluruh tidak merokok yaitu 93 responden (93\%) dan Kecemasan bahwa hampir separuhnya termasuk kategori kecemasan sedang yaitu 39 responden $(39 \%)$.

\section{Gambaran kejadian gastritis pada remaja} Tabel 2 Kejadian Gastritis pada Remaja

\begin{tabular}{lcc}
\hline \multicolumn{1}{c}{ Kejadian Gastritis } & F & $(\mathbf{\%})$ \\
\hline Gastritis & 59 & $59 \%$ \\
Tidak gastritis & 41 & $41 \%$ \\
\hline
\end{tabular}

Berdasarkan hasil penelitian menunjukkan bahwa sebagian besar responden memiliki riwayat gastritis sebanyak $59(59 \%)$ responden.

\section{Hubungan faktor-faktor yang berhubungan dengan kejadian gastritis pada remaja}

1. Hubungan Usia Dengan Kejadian Gastritis Pada Remaja

Dari hasil penelitian diketahui sebagian besar responden 65 (65\%) berada di usia 12-16 tahun yang termasuk ke dalam kategori masa remaja awal. Berdasarkan hasil uji statistik menggunakan software SPSS 22 Spearman rank diperoleh nilai $p$ value 0.002 dengan nilai alpha $a<0.05$. Oleh karena itu $\mathrm{H}_{0}$ ditolak $\mathrm{H}_{1}$ diterima. Nilai koefisien korelasi didapatkan hasil 0.303 termasuk ke dalam nilai koefisien korelasi (0.20-0.399) menunjukkan bahwa kekuatan korelasi lemah. Sehingga diketahui terdapat hubungan antara usia dengan kejadian gastritis pada remaja di Bandung. Penelitian ini sesuai dengan penelitian Diatsa (2016) dikarenakan ada karakteritik responden yang sama yaitu usia dan jenis kelamin, dapat disimpulkan bahwa terdapat hubungan antara usia remaja dengan kejadian gastritis, dan diperoleh nilai $p$-value $(0.000)<0.05$ dan nilai koefisien korelasi 0.636 menunjukkan bahwa kekuatan korelasi kuat. Penelitian diatsa (2016) mengatakan bahwa yang paling banyak menderita penyakit gastritis adalah responden yang berusia 16 tahun yaitu sebanyak 19 responden $(63,3 \%)$ dari total 30 jumlah responden. Usia 16 tahun termasuk ke dalam kategori masa remaja awal. Para remaja dituntun untuk hidup mandiri yang sebelumnya sangat bergantung dengan orang tua. Menurut Soetjiningsih (2010) usia adalah salah satu faktor resiko terjadinya gastritis, terutama pada masa remaja adalah masa peralihan dari yang sangat bergantung dengan orang tua ke masa yang penuh tanggung jawab serta keharusan untuk hidup mandiri dan usia tersebut cenderung kurang memperhatikan kesehatan mereka, karena alasan kesibukan dan remaja memiliki aktifitas yang sangat padat.

Asumsi peneliti usia berhubungan dengan kejadian gastritis ini terjadi karena adanya keinginan remaja untuk tetap memiliki tubuh yang ideal yang dianggap ideal oleh para remaja yaitu bentuk tubuh yang langsing dan membuat pola makan nya berantakan, dan remaja berusaha untuk dapat diterima oleh teman sebayanya dan mulai tertarik oleh lawan jenis yang dapat menyebabkan remaja sangat menjaga penampilan, dari semua faktor itu sangat mempengaruhi pola makan remaja, termasuk pemilihan bahan makanan dan frekuensi makan. Seusia remaja sangat takut gemuk sehingga remaja menghindari sarapan dan makan siang atau hanya makan sehari sekali saja, dari hasil penelitian yang didapatkan maka peneliti berasumsi bahwa usia 16 tahun yang termasuk ke dalam kategori masa remaja awal bisa mengalami kejadian gastritis yang disebabkan oleh pola makan yang tidak teratur, jenis makanan dan cemas. Sesuai teori yang ada Hurlock, Elizabeth B. (2013). Usia masa remaja adalah masa yang sangat penting dalam rentang kehidupan manusia, masa transisi atau peralihan dari masa kanak-kanak menuju kemasa dewasa, masa mencari identitas diri, adanya keinginan untuk dapat diterima oleh teman sebaya dan mulai tertarik pada lawan jenis dan membuat remaja sangat menjaga penampilannya dan terjebak dengan pola makan yang salah. Remaja sering memiliki pemahaman bahwa tubuh idaman ialah tubuh yang langsing, sehingga untuk mempertahankan kelangsingannya remaja melakukan pengaturan makan yang salah dan usia remaja, usia yang mudah tertarik dengan hal-hal baru, termasuk produk makanan yang diiklankan padahal makanan tersebut belum tentu memiliki kandungan gizi yang baik. 


\section{Hubungan Jenis Kelamin Dengan Kejadian Gastritis Pada Remaja}

Berdasarkan hasil penelitian menunjukkan bahwa sebagian besar responden menyatakan memiliki riwayat gastritis sebanyak $59 \quad(59 \%)$ responden, sebagian besar responden berjenis kelamin perempuan sebanyak $67(67 \%)$ responden. Berdasarkan hasil uji statistik menggunakan software SPSS 22 Spearman rank diperoleh nilai $p$ value 0.530 dengan nilai alpha $a<0.05$, oleh karena itu $\mathrm{H}_{0}$ diterima $\mathrm{H}_{1}$ ditolak. Nilai koefisien korelasi didapatkan hasil 0.064 termasuk ke dalam nilai koefisien korelasi (0.00-0.199) menunjukkan bahwa kekuatan korelasi sangat lemah. Sehingga diketahui tidak terdapat hubungan antara jenis kelamin dengan kejadian gastritis pada remaja di Bandung. Penelitian ini sesuai dengan penelitian Sunarmi (2018) disimpulkan bahwa tidak ada hubungan antara jenis kelamin dengan kejadian gastritis dengan $p$-value $(0,884)>0,05$. Akan tetapi dari hasil ini berbeda dengan hasil penelitian yang dilakukan oleh Rantung (2019) menunjukkan bahwa terdapat hubungan antara jenis kelamin dengan kejadian gastritis, dengan kata lain perempuan lebih berisiko untuk terjadinya gastritis, hal ini disebabkan karena wanita sering diet terlalu ketat, karena takut gemuk, makan tidak beraturan, dan perempuan lebih sibuk pada tugas sehingga menyebabkan telat makan yang dapat menimbullkan asam lambung meningkat. Hasil penelitian yang di dapatkan makan peneliti berasumsi bahwa jenis kelamin tidak berhubungan dengan kejadian gastritis, dikarenakan hal ini bisa disebabkan karena baik perempuan maupun lakilaki pola makan atau jenis makanan yang dikonsumsi tidak jauh berbeda, walaupun perempuan lebih sering mengkonsumsi makanan pedas, asam, berminyak, namun banyak pula lakilaki yang hobi mengkonsumsi makanan pedas, asam, berminyak, sehingga baik perempuan maupun laki-laki rentan terkena gastritis.

\section{Hubungan Pola Makan Dengan Kejadian \\ Gastritis Pada Remaja}

Berdasarkan hasil penelitian menunjukkan bahwa sebagian besar responden menyatakan memiliki riwayat gastritis sebanyak 59 (59\%) responden, hampir separuhnya pola makan kurang baik dengan angka 47 (47\%). Berdasarkan hasil uji statistik menggunakan software SPSS 22 Spearman rank diperoleh nilai p-value 0.000 dengan nilai alpha $a<0.05$, oleh karena itu $\mathrm{H}_{0}$ ditolak $\mathrm{H}_{1}$ diterima. Nilai koefisien korelasi didapatkan hasil 0.494 termasuk ke dalam nilai koefisien korelasi (0.40-0.599) menunjukkan bahwa kekuatan korelasi sedang. Sehingga diketahui terdapat hubungan antara pola makan dengan kejadian gastritis pada remaja. Jika dilihat kembali dari data usia sebagian besar responden termasuk ke dalam usia remaja awal 12-16 tahun yaitu 67 respoden (67\%), usia ini cenderung kurang memperhatikan makanan dan kesehatan mereka dikarenakan kesibukan mereka baik di akademik maupun non akademik, hal ini membuat para remaja sulit mengatur pola makan yang baik, dari hasil pengamatan yang dilakukan peneliti responden termasuk kategori kurang baik.

Hasil penelitian ini sesuai dengan penelitian Uwa (2019) menunjukkan bahwa terdapat hubungan antara pola makan dengan kejadian gastritis, diketahui bahwa pola makan yang tidak teratur akan membuat lambung sulit untuk beradaptasi, Pada saat perut yang harusnya diisi tetapi malah dibiarkan kosong atau ditunda pengisiannya, makan terlalu sedikit, terlalu banyak mengkonsumsi junk food maka merangsang asam lambung akan meningkat dan jika hal itu berlangsung lama, produksi asam lambung akan berlebihan sehingga dapat mengiritasi dinding mukosa pada lambung yang bisa menyebabkan gastritis, dan penyakit gastritis ini dapat menyerang usia produktif. Pada usia produktif rentan terserang karena kesibukan serta gaya hidup yang kurang sehingga kesehatan mudah menjadi faktor terkena penyakit gastritis.

\section{Hubungan Konsumsi Alkohol Dengan Kejadian Gastritis Pada Remaja}

Berdasarkan hasil penelitian menunjukkan bahwa sebagian besar responden menyatakan memiliki riwayat gastritis sebanyak 59 (59\%) responden, hampir seluruhnya 99 (99\%) tidak pernah mengkonsumsi alkohol. Berdasarkan hasil uji statistik menggunakan software SPSS 22 Spearman rank diperoleh nilai p-value 0.407 dengan nilai alpha $a<0.05$, oleh karena itu $\mathrm{H}_{0}$ diterima $\mathrm{H}_{1}$ ditolak. Nilai koefisien korelasi didapatkan hasil 0.084 termasuk ke dalam nilai koefisien korelasi (0.00-0.199) menunjukkan bahwa kekuatan korelasi sangat lemah. Sehingga diketahui tidak terdapat hubungan antara alkohol dengan kejadian gastritis pada remaja.

Mengkonsumsi alkohol yang sangat berbahaya bagi tubuh, karena alkohol mengandung etil alkohol atau etanol yg bersifat iritan dan korosif. Konsumsi alkohol dalam jumlah sedikit akan merangsang produksi asam lambung berlebih, nafsu makan berkurang, dan mual, hal tersebut merupakan gejala dari penyakit gastritis. Sedangkan dalam jumlah banyak alkohol dapat mengiritasi mukosa lambung dan duodenum juga memperburuk gejala tukak peptik, dan menganggu penyembuhan tukak peptik (Wahyudi \& Andinawati, 2018).

Hasil penelitian ini berbeda dengan hasil penelitian sebelumnya yang dilakukan oleh Wijaya (2016) menunjukkan bahwa terdapat hubungan antara konsumsi alkohol dengan kejadian gastritis 
p-value $(0.001)<0.05$. jika dilihat kembali perbedaan antara hasil penelitian ini bahwa hampir seluruhnya yaitu 99 responden tidak mengkonsumsi alkohol sedangkan penelitian yang dilakukan olehh wijaya dimana responden yang mengkonsumsi alkohol sebanyak $158(63,2 \%)$, dan yang tidak mengkonsumsi alkohol sebanyak $92 \quad(36,8 \%)$ dengan rentang usia antara 15-22 tahun.

\section{Hubungan Konsumsi Kopi Dengan Kejadian Gastritis Pada Remaja}

Berdasarkan hasil penelitian menunjukkan bahwa sebagian besar responden menyatakan memiliki riwayat gastritis sebanyak 59 (59\%) responden, separuhnya $50(50 \%)$ tidak pernah mengkonsumsi kopi. Berdasarkan hasil uji statistik menggunakan software SPSS 22 Spearman rank diperoleh nilai $p$-value 0.024 dengan nilai alpha $a<$ 0.05 , oleh karena itu $\mathrm{H}_{0}$ ditolak $\mathrm{H}_{1}$ diterima. Nilai koefisien korelasi didapatkan hasil 0.226 termasuk ke dalam nilai koefisien korelasi (0.20-0.399) menunjukkan bahwa kekuatan korelasi lemah. Sehingga diketahui terdapat hubungan antara kopi dengan kejadian gastritis pada remaja. Penelitian ini sesuai dengan penelitian Selviana (2015) menunjukkan bahwa terdapat hubungan antara mengkonsumsi kopi dengan kejadian gastritis.

Kopi adalah minuman yang terdiri dari berbagai jenis bahan dan senyawa kimia, termasuk lemak, karbohidrat, asam amino, asam nabati yang disebut dengan fenol, vitamin dan mineral. Kopi diketahui merangsang lambung untuk memproduksi asam lambung sehingga menciptakan lingkungan yang lebih asam dan dapat mengiritasi lambung. Iritasi lambung tersebut menyebabkan penyakit maag atau gastritis. Orang yang mengidap penyakit maag mempunyai asam lambung yang sensitif (Sani \& Jufri, 2016).

Kafein di dalam kopi dapat mempercepat proses terbentuknya asam lambung. Hal ini membuat produksi gas dalam lambung berlebih sehingga sering mengeluhkan sensasi kembung di perut, kafein juga tersedia secara luas, banyak dipasarkan, dan dapat diterima secara sosial, bahkan di kalangan populasi usia remaja karena dipercaya dapat memengaruhi performa atau kinerja dan keadaan mental dengan mengurangi atau menghilangkan rasa ngantuk (Imayani \& Aritonang, 2019). Jika dilihat dari konsumsi kopi diketahui bahwa responden termasuk sering konsumsi kopi sebagian kecil yaitu 7 responden (7\%), hampir separuhnya responden termasuk katagori kadang-kadang konsumsi kopi yaitu 43 responden (43\%) dengan angka kejadian gastritis pada remaja sebanyak $59(59 \%)$ responden.

\section{Hubungan Merokok Dengan Kejadian Gastritis Pada Remaja}

Berdasarkan hasil penelitian menunjukkan bahwa sebagian besar responden menyatakan memiliki riwayat gastritis sebanyak 59 (59\%) responden, hampir seluruh 93 (93\%) responden tidak merokok. Berdasarkan hasil uji statistik menggunakan software SPSS 22 Spearman rank diperoleh nilai dengan $p$-value 0.012 dengan nilai alpha $a<0.05$, oleh karena itu $\mathrm{H}_{0}$ ditolak $\mathrm{H}_{1}$ diterima. Nilai koefisien korelasi didapatkan hasil 0.249 termasuk ke dalam nilai koefisien korelasi (0.20-0.399) menunjukkan bahwa kekuatan korelasi lemah. Sehingga diketahui terdapat hubungan antara merokok dengan kejadian gastritis pada remaja.

Dari hasil analisis didapatkan remaja yang tidak merokok (93\%). Berdasarkan analisis bivariat didapatkan $p$-value $(0.012)<0.05$ hal ini menunjukkan bahwa variabel merokok dengan kejadian gastritis memiliki hubungan. Penelitian ini sesuai dengan Naisali (2017) menunjukkan bahwa terdapat hubungan antara perilaku merokok dengan kejadian gastritis, perilaku perokok berusia antara 15 sampai 16 tahun yang termasuk ke dalam kelompok remaja awal. Merokok dapat meningkatkan asam lambung, melambatkan kesembuhan dan meningkatkan resiko kanker lambung, dan orang yang merokok lebih sensitive terhadap gastritis maupun ulser.

\section{Hubungan Kecemasan Dengan Kejadian Gastritis Pada Remaja}

Berdasarkan hasil penelitian menunjukkan bahwa sebagian besar responden menyatakan memiliki riwayat gastritis sebanyak 59 (59\%) responden, hampir separuhnya 39 (39\%) mengalami kecemasan dalam kategori sedang. Berdasarkan hasil uji statistik menggunakan software SPSS 22 Spearman rank diperoleh nilai $p$ value 0.000 dengan nilai alpha $a<0.05$. Oleh karena itu $\mathrm{H}_{0}$ ditolak $\mathrm{H}_{1}$ diterima. Nilai koefisien korelasi didapatkan hasil 0.370 termasuk ke dalam nilai koefisien korelasi (0.20-0.399) menunjukkan bahwa kekuatan korelasi lemah. Sehingga diketahui terdapat hubungan antara kecemasan dengan kejadian gastritis pada remaja.

Asumsi peneliti cemas berhubungan dengan kejadian gastritis, hal ini terjadi karena adanya pengaruh dari diri sendiri dan cemas juga bisa terjadi karena pengaruh teman sebaya, remaja yang tidak diterima oleh teman-teman sebayanya biasanya akan menderita, tertutup. Cemas yang berkepanjangan menjadi pemicu munculnya gastritis karena dapat menyebabkan aliran darah ke mukosa dinding lambung berkurang sehingga terjadi peningkatan permeabilitas dinding lambung. 
Cemas juga erat kaitannya dengan usia, bahwa usia 12-16 tahun yang termasuk ke dalam kategori masa remaja awal, merupakan usia muda dan usia produktif. Usia ini rentan mengalami kejadian gastritis karena pada umumnya pada usia tersebut setiap orang atau pelajar disibukkan oleh banyaknya aktifitas dan tugas-tugas yang diberikan oleh sekolah yang membuat pola makan mereka menjadi tidak teratur dan tidak sehat, sehingga membuat jadwal makan para responden sering menunda waktu makan, dan untuk mempersingkat waktu para responden memilih makan-makanan cepat saji atau junk food. Hal ini membuat para responden mengalami kejadian gastritis

Penelitian ini sesuai dengan Antu (2018) menunjukkan bahwa terdapat hubungan antara cemas dengan kejadian gastritis. Gangguan cemas pada diri sendiri yang berlebih tanpa alasan yang tepat, kuatir bahkan merasa takut, erat kaitannya dengan kenaikan asam lambung dan dapat memicu gangguan pencernaan. Cemas itu sendiri dapat merangsang peningkatan produksi asam lambung dan gerakan persitaltik lambung, cemas juga akan mendorong gesekan antara makanan dan dinding lambung menjadi bertambah kuat. Cemas juga merupakan sebuah keadaan yang dapat kita alami ketika ada sebuah ketidaksesuaian yang diterima dengan kemampuan untuk mengatasinya.

\section{SIMPULAN}

Berdasarkan hasil penelitian yang sudah dilakukan maka didapatkan kesimpulan sebagai berikut:

1. Gambaran kejadian gastritis dari hasil penelitian menunjukkan bahwa sebagian besar responden $59(59 \%)$ mengalami kejadian gastritis

2. Terdapat hubungan antara usia dengan kejadian gastritis pada remaja di Bandung dengan hasil uji statistik nilai $p$-value $0.002(\mathrm{p}=<0.05)$.

3. Tidak terdapat hubungan antara jenis kelamin dengan kejadian gastritis pada remaja di Bandung, dengan hasil uji statistik nilai $p$-value $0.530(\mathrm{p}=<0.05)$

4. Terdapat hubungan antara pola makan dengan kejadian gastritis pada remaja Di Bandung, dengan hasil uji statistik nilai $p$-value $0.000(\mathrm{p}=$ $<0.05)$.

5. Tidak terdapat hubungan antara mengkonsumsi alkohol dengan kejadian gastritis pada remaja di Bandung, dengan hasil uji statistik nilai $p$-value $0.407(\mathrm{p}<0.05)$

6. Terdapat hubungan antara mengkonsumsi kopi dengan kejadian gastritis pada remaja di Bandung, dengan hasil uji statistik nilai $p$-value $0.024(\mathrm{p}=<0.05)$.

7. Terdapat hubungan yang signifikan antara perilaku merokok dengan kejadian gastritis pada remaja di Bandung, dengan hasil uji statistik nilai $p$-value $0.012(\mathrm{p}=<0.05)$.

8. Terdapat hubungan yang signifikan antara kecemasan dengan kejadian gastritis pada remaja di Bandung, dengan hasil uji statistik nilai $p$-value $0.000(\mathrm{p}=<0.05)$.

Berdasarkan dari hasil kesimpulan penelitian di atas, maka dapat diberikan saran sebagai berikut:

1. Bagi pelayanan Kesehatan atau keperawatan, dapat memberikan penyuluhan secara berkala dengan media promosi Kesehatan seperti brosur atau leaflet, booklet sehingga dapat menambah pengetahuan dan pemahaman tentang bagaimana faktor-faktor yang berhubungan dengan kejadian gastritis pada remaja.

2. Bagi peneliti selanjutnya, Diharapkan peneliti selanjutnya untuk menambah jumlah responden sehngga lebih menggambarkan faktor-faktor gastritis dan dapat mengembangkan karakteristik responden yang diteliti.

\section{DAFTAR PUSTAKA}

Antu, A. (2018). Hubungan Kecemasan Dengan Kejadian Gastritis di RSUD Toto Kabila Kabupaten Bonebolango. Skripsi: Universitas Negeri Gorontalo.

Ardiansyah, M. (2012). Medikal bedah untuk mahasiswa. Jogjakarta: Diva Press.

Diatsa, B (2016), Hubungan pola makan dengan kejadian gastritis pada remaja di pondok $\mathrm{AL}$ Hikmah Trayon Karang Gede Boyolali., Skripsi.

http://eprints.ums.ac.id/47262/39/NASKAH \%20PUBLIKASI.pdf

Hurlock, Elizabeth B., (2013). Psikologi Perkembangan: Suatu Pendekatan Sepanjang Rentang Kehidupan. Jakarta: Erlangga.

Huzaifah, Z. (2017). Hubungan Pengetahuan Tentang Penyebab Gastritis dengan Perilaku Pencegahan Gastritis. Journal Healthy-Mu, 1(1), 28-31.

Imayani, S., CH, M., \& Aritonang, J. (2019). Gastritis Dan Faktor-Faktor Yang Berpengaruh (Studi Kasus Kontrol) Di Wilayah Kerja Puskesmas Bebesen Kabupaten Aceh Tengah Tahun (2017). Jurnal Riset Kesehatan Nasional, 1(2), 132144.

Kemenkes, (2015). Peraturan Menteri Kesehatan Republik Indonesia Nomor 28 Tahun (2013) tentang Pencantuman Peringatan Kesehatan Dan Informasi Kesehatan Pada Kemasan Produk Tembakau, Jakarta: Kementerian Kesehatan RI. 
Eli Kurniasih, Anih Kurnia \& Laila Fitri Istiqomah / Pengaruh Terapi Spiritual (Islam) Terhadap Penurunan Tingkat Kecemasan pada Pasien Hemodialisa

Malda, P., (2018). Hubungan Pola Makan Dengan Kejadian Gastritis di Wilayah Kerja Puskesmas Kuranji Kota. Skripsi: Universitas Andalas.

Muhith, A., dan Siyoto, S., M., (2016). Pengaruh Pola Makan dan Merokok Terhadap Kejadian Gastritis Pada Lansia Effect of Diet and Smoking on The Occurrence Gastritis of Elderly. IX(3).

Naisali, M., N., Rona, S., M., P., \& Tri, N. (2017). Hubungan Perilaku Merokok dengan Kejadian Gastritis pada Mahasiswa Teknik Sipil Universitas Tribhuwana Tunggadewi Malang. Nursing News: Jurnal Ilmiah Keperawatan, 2(1), 307.

Rantung, Elizabeth. P., \& Malonda, Nancy. S. H. (2019). Faktor-faktor yang Memengaruhi Kejadian Gastritis di Puskesmas Ranotana Weru Kota Manado. eBiomedik, 7(2), 130132.

Saydam, G. (2011). Memahami Berbagai Penyakit. Bandung: Alfabeta.

Sani, W., Tina, L., \& Jufri, N. (2016). Analisis faktor kejadian penyakit gastritis pada petani nilam di wilayah kerja puskesmas tiworo selatan kab. muna barat desa kasimpa jaya tahun (2016). Jurnal Ilmiah Mahasiswa Kesehatan Masyarakat, 1(4), 1-12.

Soetjiningsih. 2010. Tumbuh Kembang Remaja dan Permasalahannya. Jakarta: Sagung Seto.

Sunarmi (2018), Faktor-faktor yang beresiko dengan kejadian penyakit gastritis di Poliklinik penyakit dalam RS Muhamadiyah Palembang. Babul Ilmi_Jurnal Ilmiah Multi Science Kesehatan, Volume 8 hal. 61-75.

Uwa, L. F., Milwati, S., \& Sulasmini, S. (2019). Hubungan Antara Stres Dan Pola Makan Dengan Kejadian Gastritis Yang Terjadi Di Puskesmas Dinoyo. Nursing News: Jurnal Ilmiah Keperawatan, 4(1). 243-245.

Wahyudi, A., Kusuma, F. H. D., \& Andinawati, M. (2018). Hubungan antara kebiasaan mengkonsumsi minuman keras (alkohol) dengan kejadian gastritis pada remaja akhir (18-21 tahun) di asrama putra papua kota malang. Nursing News: Jurnal Ilmiah Keperawatan, 3(1), 686-696.

Wijaya, A. (2016). Faktor-faktor Yang Mempengaruhi Tingginya Konsumsi Alkohol Pada Remaja Putra Di Desa Keramas Kecamatan Blahbatuh Kabupaten Gianyar. Jurnal Dunia Kesehatan, 5(2), 1721.

Wijaya, A.S dan Putri, Y.M. 2013. Keperawatan Medikal Bedah 2, Keperawatan Dewasa
Teori dan Contoh Askep. Yogyakarta: Nuha Medik. 
Jurnal Keperawatan Galuh, Vol.3 No.1 (2021) 21 - 28 